\title{
THE IMPACT OF DIGITAL TRANSFORMATION ON INNOVATION MANAGEMENT
}

\author{
Dorota JELONEK; Cezary STEPNIAK \\ Czestochowa University of Technology, Faculty of Management
}

\begin{abstract}
Digital transformation is a specific organisational change resulting from the evolution of new information and communication technologies. The digital technologies that are most significantly changing not only business models but also innovation management are: social media, mobile technologies, analytics and Big Data, cloud computing and the Internet of Things. Over the years, innovation has become open, global, and collaborative in nature and involves diverse stakeholders and distributed innovation processes.

Purpose: The aim of the research was to find answers to the following research question: How does digital transformation influence the realization and effectiveness of the innovation processes? In addition, the digital technologies that have the greatest impact on the effectiveness of each stage in the innovation management process were identified.

Design/methodology/approach: An interview method with managers of large enterprises was used.

Findings: Research has shown that the use of appropriately selected digital technologies to implement particular stages of innovation creation increases the effectiveness of these processes. The study has proven that digital transformation facilitates the creation of collaborative innovations. The research also proved that focusing on customers and creating innovations that meet their needs allows companies to increase their competitiveness.
\end{abstract}

Key words: digital transformation, innovation management, digital technologies

\section{Introduction}

Implementation of new technologies, digitization of data, and automation of processes are no longer just a lever for growth, but a precondition for survival and competitiveness of companies. The digital revolution has greatly accelerated in recent years, and, despite the difficulties caused by the COVID-19 pandemic, spending on digital transformation technologies and services has increased by more than 10 percent. (IDC 2019). Therefore, the resilience of this market to unpredictable economic fluctuations shows how much importance companies attach to the digitization and how high their expectations are. According to the 2020 Veeam report, nearly one-third (30\%) of businesses around the world are beginning to conduct or at least plan digital transformation.

The Digital Transformation of Companies survey conducted at the request of EY by CubeResearch in October 2020 (sample of 989 respondents) shows that according to $57 \%$ of respondents, the pandemic has accelerated the digital transformation of Polish companies. The vast majority of entrepreneurs (82\%) confirm that digital transformation is an evolutionary but inevitable process, the implementation of

https://doi.org/10.11118/978-80-7509-820-7-0279

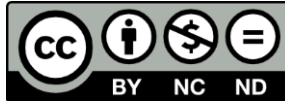


which requires a change in mindset and many previous habits. Nearly a quarter of respondents (22\%) rated their company's digital transformation as advanced, while just over half $(55 \%)$ rated it as medium. A low level of digital transformation was indicated by $23 \%$ of respondents (Transformacja...2020). The presented results also confirm that one of the objectives of digital transformation is to meet customer needs, which is associated with the development of business innovation. The use of different information technology solutions in innovation management is practiced in many companies, However, it is worth including the digitization of innovation management processes in the strategy of digital transformation of business processes. The following stages were distinguished in the process of innovation management: search, select, implement and capture value and benefits. Of many ICT solutions, those that managers believe should be used to support each stage of the innovation management process were selected. The paper presents the concept of using ICT solutions as a support for innovation processes management.

The research aimed to find answer to the following research question:

How does digital transformation influence the realization and effectiveness of the innovation processes? Furthermore, the digital technologies that have the greatest impact on the effectiveness of each stage in the innovation management process were identified.

\section{Literature review}

Digital transformation is the process of making disruptive changes in approaching customers and conducting business, using digital technologies and leading to innovative products, services, processes, or business models (Digitalizacja 2019). The determinants of taking up the challenge of digital transformation in a company include the expectations of customers towards new communication channels and access to services, the expectations of managers towards improved meeting and anticipating customer needs due to transformation of business processes, and the expectations of employees, who want to improve the conditions of their employment.

The main inspirations for Polish companies to start digitization are changing customer expectations and the availability of new technologies (Jelonek, Turek 2019).

In this context, it is unsurprising that companies are increasingly interested in implementing new digital technologies and plan such investments in their budgets. According to the 2019 IDC forecast, direct investment in digital transformation will reach $\$ 7.4$ trillion between 2020 and 2023.

Enterprises expect that the sequence of changes that every organization has to undergo during the digital transformation process will make them more agile, more innovative, and ultimately more competitive in the market. Outcomes of digitization include advanced tools for better, faster, and more efficient customer service or collecting, analyzing, and using data from different sources. 
Digital transformation means business transformation. This aspect was highlighted by the following definition: digital transformation is a specialized type of business transformation where IT plays a dominant role. In the digital age, new business opportunities arise and enterprises transform their strategy, structure, culture, and processes using the potential and power of digital media and the Internet (Uhl et al. 2016, p.15).

In the literature, problems of digital transformation have been widely discussed in relation to digital transformation strategies (Matt, Hess, Benlian 2015), digital transformation of business models (Schallmo, Williams, Boardman 2020), digital dividends, and entrepreneurship (Galindo-Martín, Castaño-Martínez, MéndezPicazo 2019), and digital transformation of innovation (Herbert 2017; Nambisan, Wright, Feldman 2019).

The speculation that innovation in the broad sense should be one of the main goals of digital transformation was confirmed by a study conducted by Digital Academy (2020). While responding to the question: "What should be the main Focus while conducting a digital transformation?", respondents indicated innovation as the third objective (16\% of indications), just after focusing on data (18\% of indications) and focusing on customer needs (52\% of indications).

Digital technologies promote openness in varied ways, and consequently, digitization has radically changed the notion of innovation and open innovation models. Internet and social media play a special role in the emergence of new models of innovation creation (Jelonek 2012). The innovation process consists of many diverse activities carried out in an orderly manner that enable the realization of a specific innovative idea and its transformation into a new state. The first stage of this process is to search, i.e. recognize market expectations and analyze emerging opportunities for change. The next stage is to select ideas for possible change, including the creation of innovative ideas and the decision to implement them. The third stage is to implement innovative projects and confront the ideas with real production capabilities. The last stage of the innovation process is to discount the value of the implemented innovative project (the capture stage).

The impact of digital transformation on innovation management at each stage (search, select, implement, and capture) is a research problem whose solution was sought in the author's study.

\section{Methodology}

An interview method with managers of large enterprises was used. Respondents were: 4 executives responsible for $\mathrm{R} \& \mathrm{D}$ departments and 1 manager responsible for customer relations. Telephone interviews were conducted in March 2021. The scenario of the interviews was the same for everyone. The questions were as follows:

Which ICT solutions are most commonly used in customer interactions?

Which ICT solutions are most effective when creating innovation? 
Is cloud computing used, and if so, how, in the four stages of innovation management?

Is social media used and if yes, how in the four stages of innovation management?

Is mobile technologies used and if yes, how in the four stages of innovation management?

Is Big Data used and if yes, how in the four stages of innovation management?

\section{Results and Discussion}

All respondents agreed that the following technologies are the most important in managing innovation: Cloud Computing, Social media, Mobile, and Big Data. They were then asked about the possibility of using each technology in stages of innovation management process: search, select, implement and capture. The most interesting answers of the respondents are presented in the table 1.

Table 1. Possibilities of using digital technologies at the innovation management process

\begin{tabular}{|l|c|}
\hline Stage & Examples of using digital solutions \\
\hline \multicolumn{1}{|c|}{ Cloud Computing } \\
\hline Search & $\begin{array}{c}\text { Use of platforms from Cloud Computing providers } \\
\text { Use of platform by customers }\end{array}$ \\
\hline Select & $\begin{array}{c}\text { Collaboration among internal and external clients anytime and anywhere e.g. } \\
\text { virtualization. }\end{array}$ \\
Use of platforms from Cloud Computing providers
\end{tabular}




\begin{tabular}{|l|c|}
\hline Capture & Real-time analysis of customer sentiments and behavior, e.g. visualization of \\
results
\end{tabular}

Source: Own elaboration based on interviews

\section{Conclusion}

In recent years, the nature of innovation has undergone dramatic changes in the majority of industry sectors. Innovation has become much more open, global, more frequent, unpredictable and also collaborative in nature involving often a diverse partners.

Digital technologies play a crucial role in enabling innovation strategies towards a digital transformation. Social media, mobile, Big Data, Cloud Computing are the most important digital technologies that can be employed to enable innovative solutions with respect to each phase of the innovation process.

\section{References}

1. Appio F.P., Frattini F., Petruzzelli A.M., Neirotti P. (2021), Digital transformation and innovation management: a synthesis of existing research and an agenda for future studies, „Journal of Product Innovation Management”, 38(1), pp. 4-20.

2. Carayannis E.G., Campbell D.F.J. (2009), 'Mode 3' and 'Quadruple Helix': Toward a 21st Century Fractal Innovation Ecosystem, „International Journal of Technology Management”, 46(3/4), pp. 201-34.

3. Digitalizacja procesów przemystowych, (2019), IDC White Paper, www.idc.com (access date: $15-05-2021)$.

4. Galindo-Martín M.Á., Castaño-Martínez M.S., Méndez-Picazo, M.T. (2019). Digital transformation, digital dividends and entrepreneurship: A quantitative analysis. „Journal of Business Research", 101, pp. 522-527.

5. Herbert L. (2017), Digital transformation: Build your organization's future for the innovation age. Bloomsbury Publishing.

6. Jelonek D., Turek T. (2019), Zarządzanie relacjami z klientami wobec wyzwań transformacji cyfrowej, In: Parys T. (ed.), Informatyka i zarządzanie na przełomie wieków. Metody, Narzędzia, Systemy, Zastosowania, pp. 203-218,Wydawnictwo Naukowe Wydziału Zarządzania Uniwersytetu Warszawskiego, Warszawa.

7. Jelonek D. (2012), The role of the internet in open innovations models development, „Informatyka Ekonomiczna”, 23, pp.38-47.

8. Matt C., Hess T., Benlian A. (2015). Digital transformation strategies, „Business \& Information Systems Engineering”, 57(5), pp. 339-343.

9. Nambisan S., Wright M., Feldman M. (2019), The digital transformation of innovation and entrepreneurship: Progress, challenges and key themes, „Research Policy”, 48(8), pp. 103773.

10. Paslawski K., 3 największe bariery cyfrowej transformacji, https://crn.pl/aktualnosci/3najwieksze-bariery-cyfrowej-transformacji/ (access date: 12-05-2021).

11. Pihir I., Tomičić-Pupek K., Furjan M.T. (2018), Digital transformation insights and trends. In: Proceedings of the Central European Conference on Information and Intelligent Systems pp. 141-149, Faculty of Organization and Informatics, Varazdin.

12. Schallmo D., Williams C.A., Boardman, L. (2020), Digital transformation of business models-best practice, enablers, and roadmap. Digital Disruptive Innovation, pp. 119-138. 
13. Transformacja cyfrowa firm 2020. Raport z wyników badania, Designed by EY Creative Services Warsaw, https://branden.biz (access date: 12-05-2021).

14. Uhl A., Born M., Koschmider A., Janasz T. (2016), The importance of Technological Trendsa nad How to Exploit Then for Business Excellence, In: Uhl A., Gollenia L.A. (ed.), The importance of Digital Enterprise Transformation. A Business-Driven Approach to Leveraging Innovative IT, pp. 1-25, Routledge, New York. 